\title{
Large Retroperitoneal Mass Diagnosed as Adrenal Chronic Expanding Hematoma.
}

\section{$\operatorname{AUTHOR}(S)$ :}

Sunada, Takuro; Kobayashi, Takashi; Furuta, Akihiro; Shibuya, Shinsuke; Okada, Yoshiyuki; Negoro, Hiromitsu; Terada, Naoki; ... Inoue, Takahiro; Kamba, Tomomi; Ogawa, Osamu

\section{CITATION:}

Sunada, Takuro ... [et al]. Large Retroperitoneal Mass Diagnosed as Adrenal Chronic Expanding Hematoma.. Urology 2015, 86(4): e17-e19

\section{ISSUE DATE:}

2015-10

URL:

http://hdl.handle.net/2433/202762

\section{RIGHT:}

(c) 2015. This manuscript version is made available under the CC-BY-NC-ND 4.0 license

http://creativecommons.org/licenses/by-nc-nd/4.0/; The full-text file will be made open to the public on 10 ctober 2016 in accordance with publisher's 'Terms and Conditions for Self-Archiving'.; This is not the published version. Please cite only the published version.; この論文は出版社版でありません。引用の際には出版社版をご確認ご利用ください。 


\section{TITLLE}

Large retroperitoneal mass diagnosed as adrenal chronoc expanding hematoma

\section{AUTHOR}

Takuro Sunada ${ }^{1}$, Takashi Kobayashi ${ }^{1}$, Akihiro Furuta ${ }^{2}$, Shinsuke Shibuya $^{3}$, Yoshiyuki Okada ${ }^{1}$, Hiromitsu Negoro ${ }^{1}$, Naoki Terada ${ }^{1}$, Toshinari Yamasaki ${ }^{1}$, Yoshiyuki Matsui ${ }^{1}$, Takahiro Inoue ${ }^{1}$, Tomomi Kamba ${ }^{1}$, Osamu Ogawa ${ }^{1 *}$

\section{AUTHOR AFFILIATIONS:}

${ }^{1}$ Department of Urology, Kyoto University Hospital, Kyoto, Japan

${ }^{2}$ Department of Diagnostic Imaging and Nuclear Medicine, Kyoto University Graduate School of Medicine, Kyoto, Japan

${ }^{3}$ Department of Diagnostic Pathology, Kyoto University Hospital, Kyoto, Japan

*Corresponding author:

Department of Urology, Kyoto University Hospital

54 Shogoinkawahara-cho, Sakyo-ku, Kyoto, 606-8507 Japan

TEL: +81-75-751-3326, FAX: +81-75-761-3441

Email: ogawao@kuhp.kyoto-u.ac.jp

WORD COUNT: 200 


\section{ABSTRACT}

Chronic expanding hematoma is defined as a structure with central mass of blood and granulation tissue encapsulated with dense fibrous membrane that slowly grows over a month. We report a case of a 67-year-old man with left adrenal chronic expanding hematoma who underwent surgical resection after 7-year surveillance, presenting natural history of an adrenal chronic expanding hematoma. 


\section{CASE PRESENTATION}

A 67-year-old man was diagnosed to have an asymptomatic left adrenal mass, diagnosed as chronic expanding hematoma based on CT scan (Figure 1) in 2007. He had been taking warfarin (2 mg/day) and aspirin (100 mg/day) since cardiac valve replacement in April 2000.

The patient refused surgery until when the mass reached $16.6 \mathrm{~cm}$ in diameter and caused gastric distress in 2014 (Figure 2). At surgery, a 16-cm, 2300-g, round and adhesive mass (Figures 3A \& B) was removed and the gastric distress was disappeared postoperatively. The final pathological diagnosis was adrenal chronic expanding hematoma (Figures 3C \& D).

Adrenal chronic expanding hematoma is very rare and only a few cases have been reported in the literature ${ }^{1-4}$ since the first report ${ }^{5}$ and definition ${ }^{6}$. Recent accumulation of radiological findings in correlation with pathological diagnosis ${ }^{1-3,7,8}$ has improved the accuracy of preoperative diagnosis of chronic expanding hematoma based on imaging studies.

This is to our knowledge the first report showing the natural history of an adrenal chronic expanding hematoma, a fairly slow but virtually constant growth over years. These findings will be helpful information for the management of adrenal chronic expanding hematoma including surgical resection and active surveillance according to the patient's age and comorbidity. 


\section{REFERENCES}

1. Khati NJ, Javitt MC and Schwartz AM: Adrenal adenoma and hematoma mimicking a collision tumor at MR imaging. Radiographics. 1999, 19: 235-239.

2. Yamada T, Ishibashi T, Saito $\mathrm{H}$ et al.: Case report: chronic expanding hematoma in the adrenal gland with pathologic correlations. J Comput Assist Tomogr. 2003, 27: 354-356.

3. Ishigami K, Stolpen AH, Sato Y et al.: Adrenal adenoma with organizing hematoma: diagnostic dilemma at MRI. Magn Reson Imaging. 2004, 22: 1157-1159.

4. Marti JL, Millet J, Sosa JA et al.: Spontaneous adrenal hemorrhage with associated masses: etiology and management in 6 cases and a review of 133 reported cases. World J Surg. 2012, 36: 75-82.

5. Friedlander HL and Bump RG: Chronic expanding hematoma of the calf. A case report. J Bone Joint Surg Am. 1968, 50: 1237-1241.

6. Reid JD, Kommareddi S, Lankerani M et al.: Chronic expanding hematomas. A clinicopathologic entity. JAMA. 1980, 244: 2441-2442.

7. Akata S, Ohkubo Y, Jinho $\mathrm{P}$ et al.: MR features of a case of chronic expanding hematoma. Clin Imaging. 2000, 24: 44-46.

8. Hoeffel C, Legmann P, Luton JP et al:: Spontaneous unilateral adrenal hemorrhage: computerized tomography and magnetic resonance imaging findings in 8 cases. J Urol. 1995, 154: 1647-1651. 


\section{FIGURE LEGENDS}

Figure 1. A-C: Pre-contrast (A), early (B) and late (C) phase images of contrast-enhanced CT scan of the mass in 2009. Contrast-enhancement is observed at the periphery in early phase and gradually and heterogeneously spread to the internal portion in late phase. D: Unenhanced CT image of the mass in 2014. Note that the enlarged mass with peripheral calcification oppresses the pancreas and stomach anteriorly (arrowheads).

Figure 2. Macroscopic (A, B) and microscopic (C, D) appearances of the resected mass lesion.

A: The mass was encapsulated with fibrous connective tissue and blood vessels. B: The mass was filled with organized blood and necrotic tissue. C, D: Representative images of H\&E stain of the lesion showing dense fibrous tissue on the periphery $(\mathrm{C})$ and erythrocytes and necrotic tissue at the center (D). Original magnification $\mathrm{x} 10$.

Figure 3 Changes in the mass volume of the present patient is plotted. The solid line is an approximate line for estimated tumor volume based on CT images, indicating that the mass grew up at almost constant rate $\left(\sim 250 \mathrm{~mm}^{3} / \mathrm{year}\right)$. Dashed line is an extention of the approximate line that intersects X axis at May 2005 . 

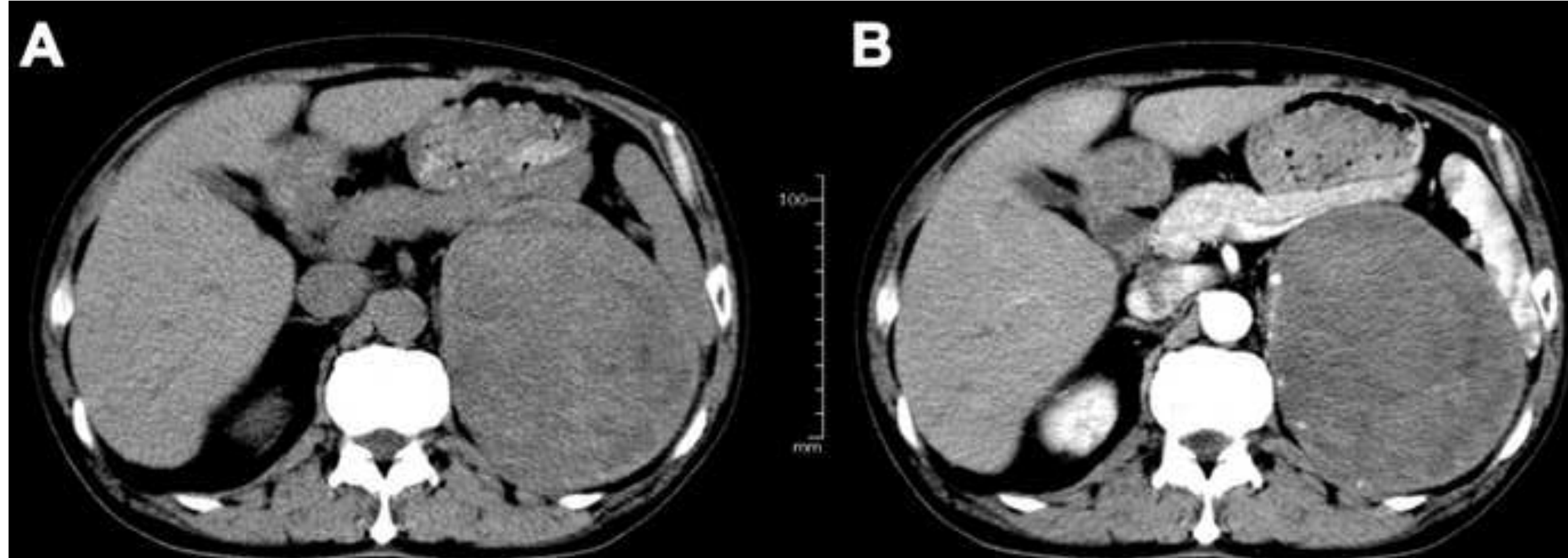

100

C
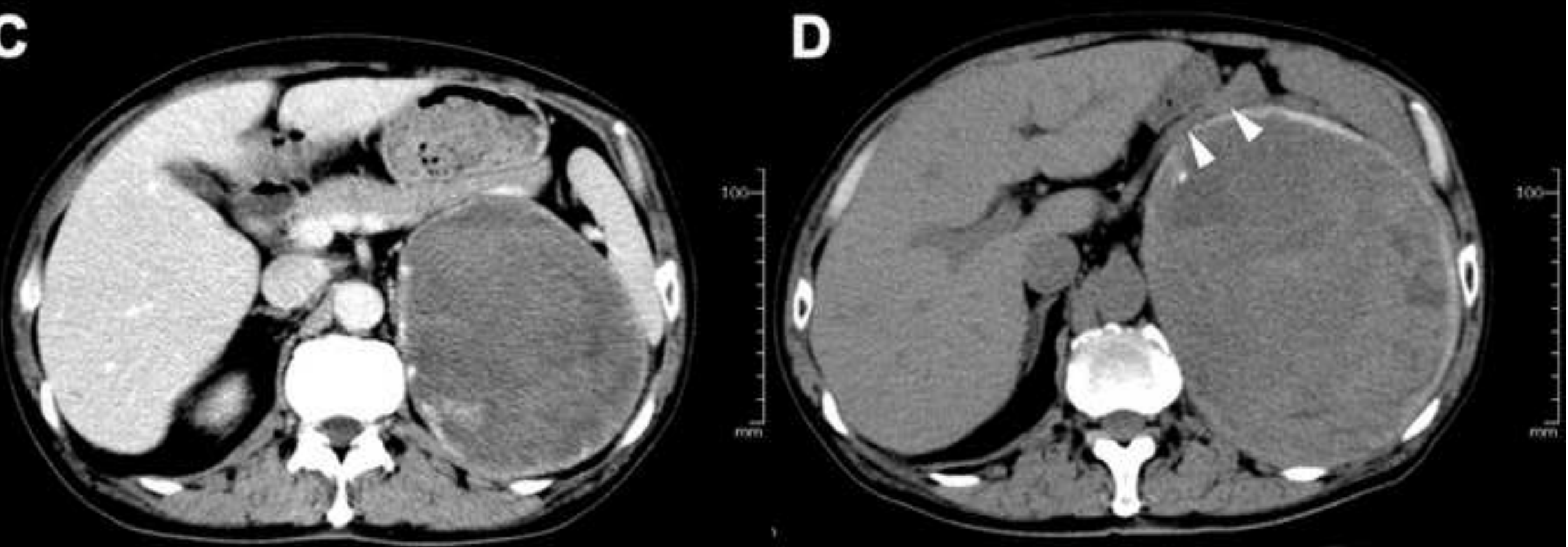


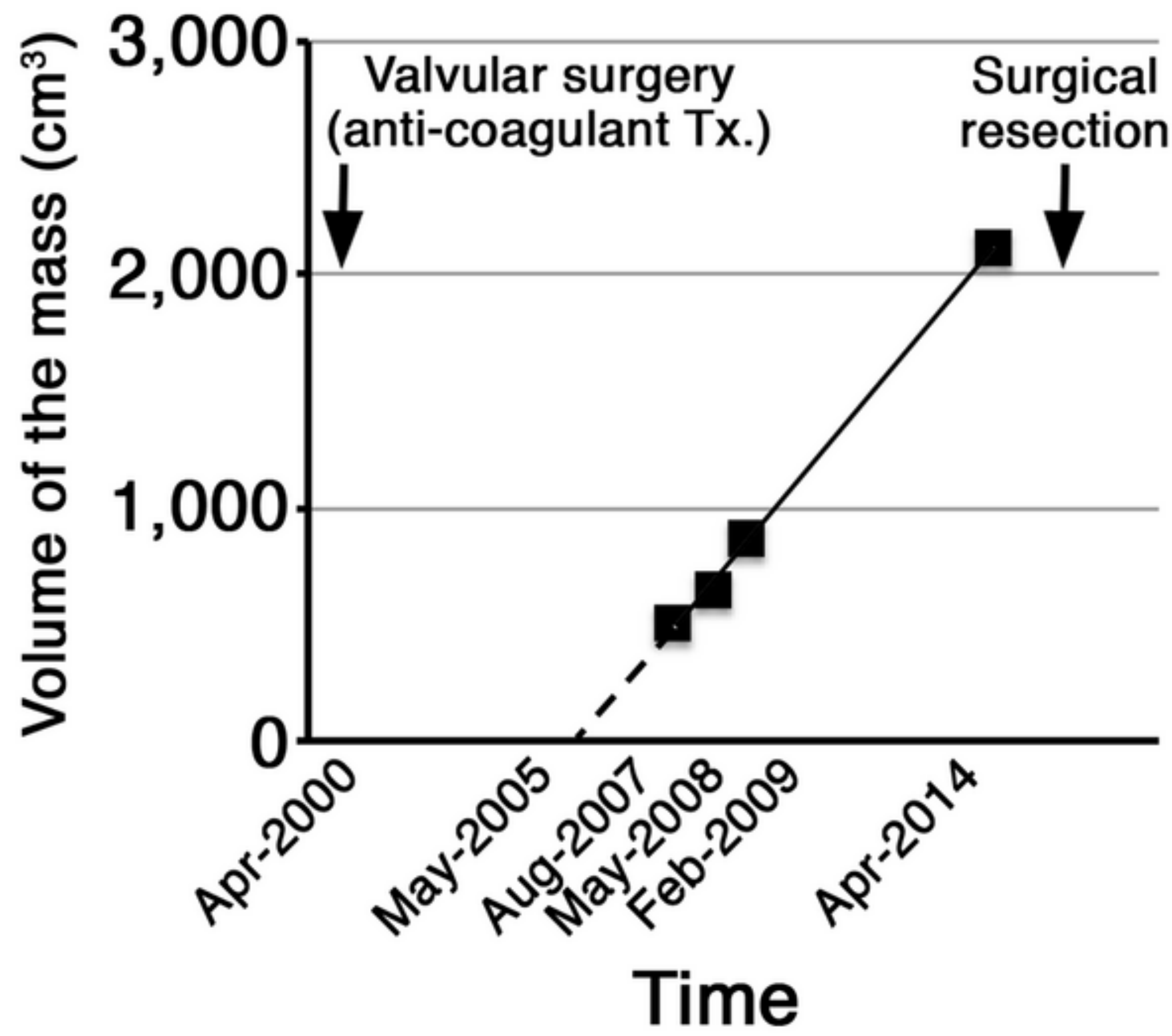




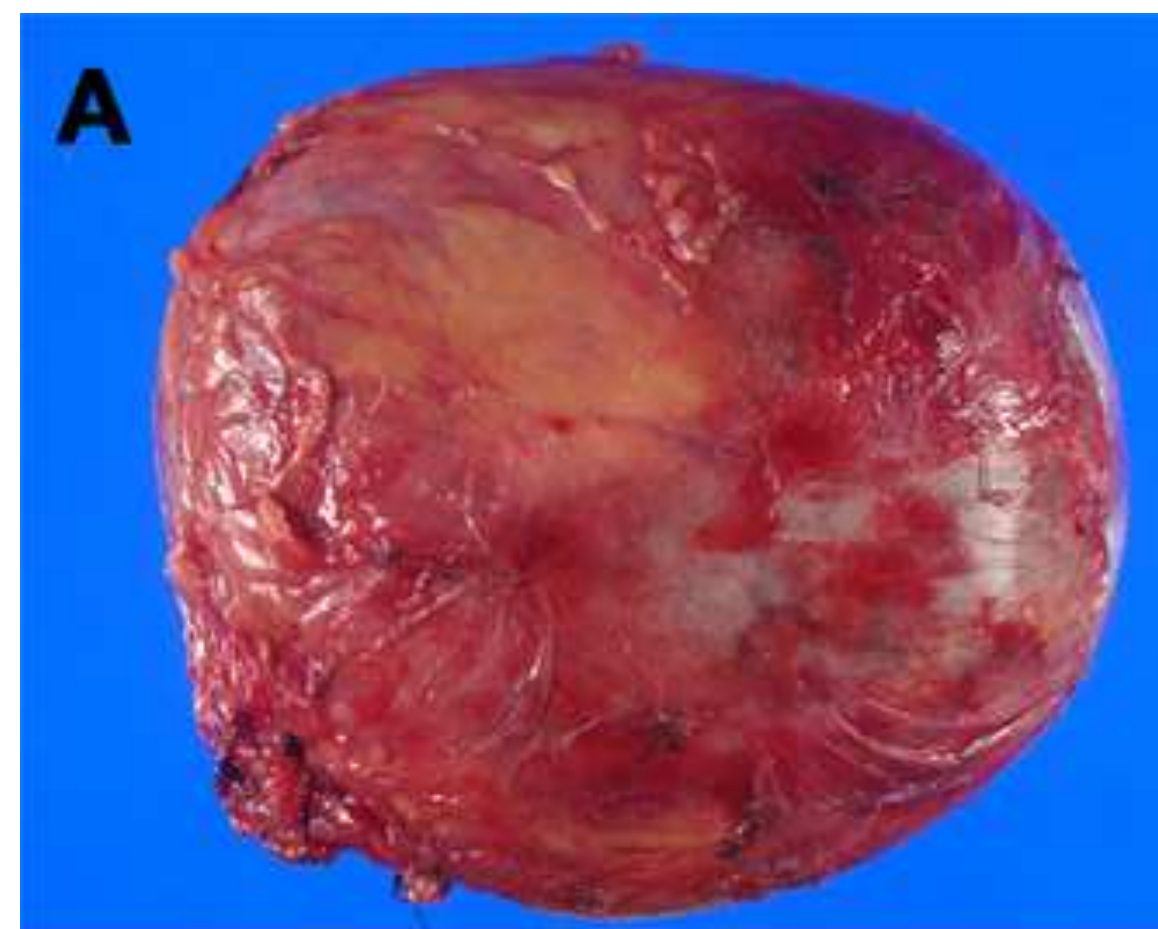

$$
\text { c }
$$
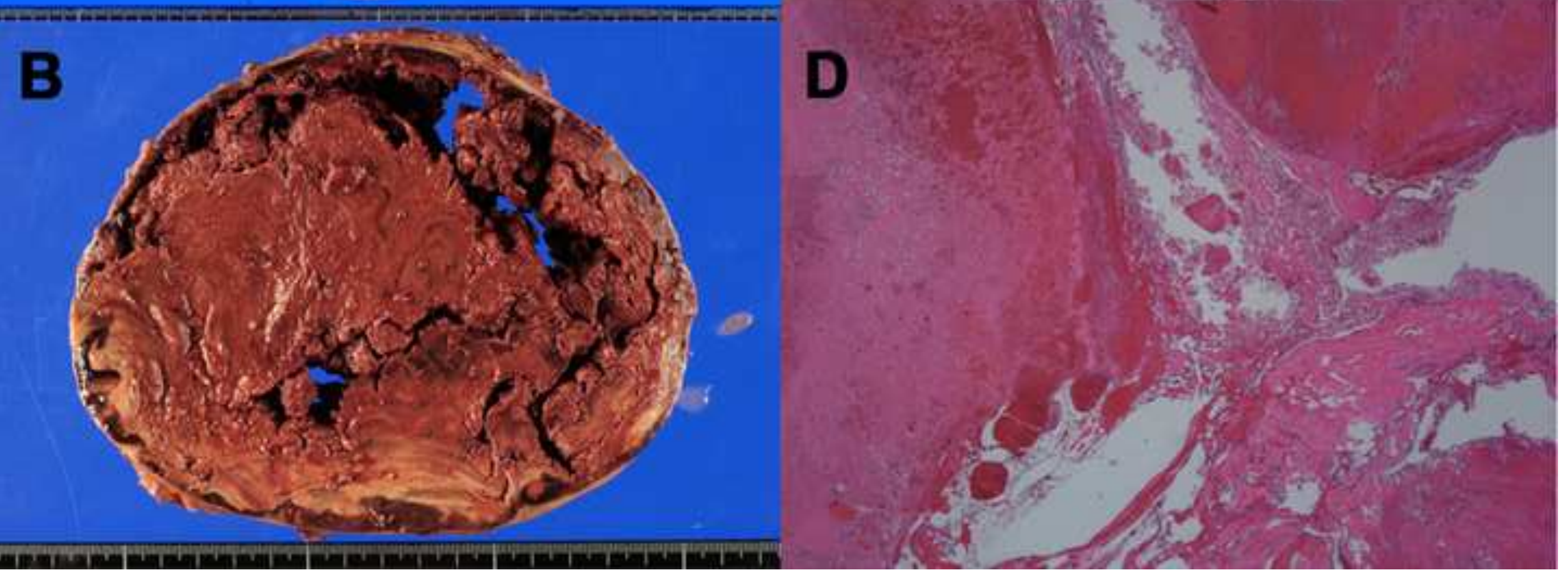


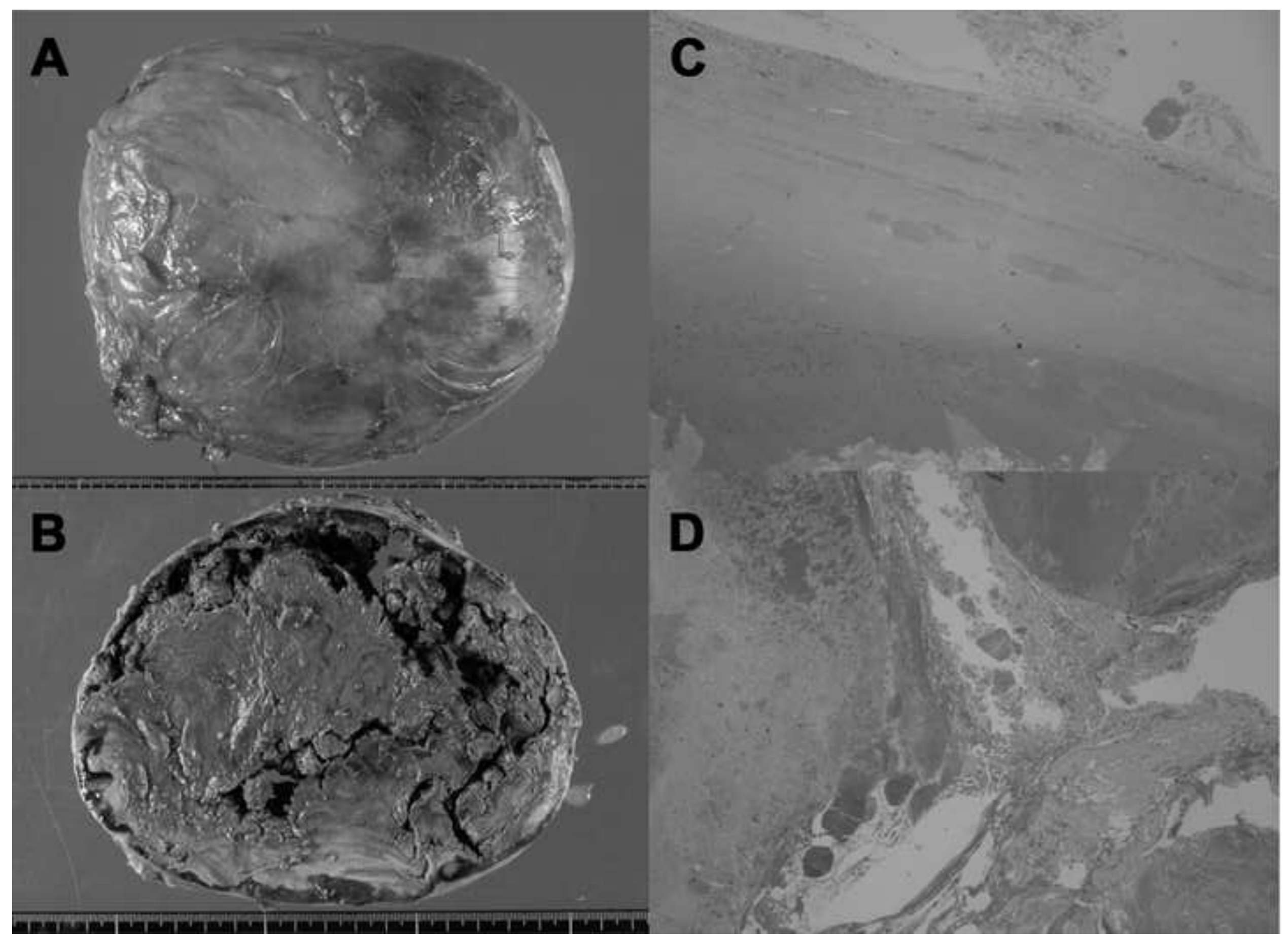

